OPTIMUM. STUDIA EKONOMICZNE NR 4 (82) 2016

\author{
dr Konrad PRANDECKI \\ Zakład Ogólnej Ekonomiki, Instytut Ekonomiki Rolnictwa i Gospodarki Żywnościowej - \\ Państwowy Instytut Badawczy \\ e-mail: kprand@interia.pl
}

DOI: $10.15290 /$ ose.2016.04.82.05

\title{
DOBRO WSPÓLNE A ZRÓWNOWAŻONY ROZWÓJ
}

\begin{abstract}
Streszczenie
Dobro wspólne jest pojęciem trudnym do jednoznacznego zdefiniowania. Kryje ono w sobie nie tylko zasoby materialne (finalne i produkcyjne) i usługi, ale również specyficzne relacje pomiędzy zarządzającymi dobrem wspólnym. Nadrzędną cechą gospodarowania na zasadach dobra wspólnego jest zapewnienie trwałości i jak najbardziej sprawiedliwego dostępu do zasobu. Takie podejście powoduje, że dominująca w ekonomii głównego nurtu zasada maksymalizacji zysku ma ograniczone zastosowanie. Z tego powodu, z ekonomicznego punktu widzenia dobro wspólne jest zazwyczaj uznawane za nieefektywne rozwiązanie. Dopiero rozwój badań nad instytucjami nieformalnymi w ramach Nowej Ekonomii Instytucjonalnej oraz przyznanie Elinor Ostrom nagrody Banku Szwecji doprowadziły do zwiększenia zainteresowania dobrem wspólnym i ukazania niewycenianych korzyści płynących z jego stosowania. Efektem sa pierwsze próby budowy nowej koncepcji ekonomicznej - ekonomii dobra wspólnego.

Analiza cech charakterystycznych dobra wspólnego pozwala na stwierdzenie, że idea ta ma wiele cech wspólnych z koncepcją rozwoju zrównoważonego. Bardziej szczegółowe badania wskazują także na istnienie licznych różnic pomiędzy tymi koncepcjami.

Celem niniejszego artykułu jest zaprezentowanie charakterystycznych cech dobra wspólnego, ocena relacji między dobrem wspólnym a rozwojem zrównoważonym oraz analiza możliwości wykorzystania dobra wspólnego we wdrażaniu koncepcji rozwoju zrównoważonego. Uzyskane wyniki skłaniaja do konstatacji, że rozwój zrównoważony jest bardziej złożoną koncepcją, w ramach której idea dobra wspólnego może być uwzględniona, jednakże za jej pomocą da się osiagnąć jedynie wybrane cele.

Opracowanie zostało przygotowane na podstawie krytycznej analizy krajowej i zagranicznej literatury. Ponadto, w procesie badawczym zastosowano metodę indukcyjną, która umożliwiła przedstawienie ogólnych wniosków.
\end{abstract}

Słowa kluczowe: dobra wspólne, zrównoważony rozwój, ochrona środowiska, dobra publiczne

\section{COMMON GOOD AND SUSTAINABLE DEVELOPMENT}

\section{Summary}

The concept of common good is a difficult one to define. Not only does it encompass material resources and services, but also specific relationships between people managing the common good. The overriding feature of management based on the common good principle is to ensure the durability and the most equitable access to the resource. Under this approach, the principle of profit maximization, dominant in mainstream economics, is of limited use. For this reason, economic activity aimed at 
achieving common good is usually regarded as an inefficient. It was only the development of research on informal institutions within the framework of the New Institutional Economics and the award for Elinor Ostrom granted by the Bank of Sweden that have led to increased interest in common good and the benefits of its use. As a result, first attempts have been made to build a new economic concept - economy for the common good.

Analysis of the characteristics of common good leads to the conclusion that this idea has much in common with the concept of sustainable development. More detailed studies also indicate the existence of numerous differences between these two concepts.

The purpose of this paper is to identify the specific characteristics of common good, to study the relationship between common good and sustainable development, and to analyse the possibilities of using common good in implementing the concept of sustainable development. The results make it possible to conclude that sustainable development is a more complex concept than that of common good. However, the latter may be effective in implementing sustainability in selected areas.

The study was prepared based on critical analysis of domestic and foreign literature, and the research process used the inductive method as a means of reaching general conclusions.

Key words: common goods, sustainable development, environmental protection, public goods

JEL: H23, H49, Q56

\section{Wstęp}

Dobro wspólne jest pojęciem używanym już od starożytności. Służy ono opisowi lub podkreśleniu wartości (zarówno materialnej, jak i niematerialnej) istotnych dla całej społeczności. Często jest ono utożsamiane z dobrem publicznym. Jednakże w naukach ekonomicznych te dwa pojęcia mają odmienne znaczenia. W praktyce ich rozróżnienie nie jest przejrzyste, co powoduje, że problematyka dobra wspólnego jest marginalizowana. Dodatkowo taką postawę determinuje wiele poglądów istniejących w ramach głównego nurtu ekonomii, które dowodzą braku efektywności w gospodarowaniu na zasadach dobra wspólnego. Najbardziej znany jest artykuł G. Hardina [1968], w którym autor konstatuje, że dobro wspólne może być zagrożeniem dla trwałości zarządzania wspólnymi zasobami. Takiemu stanowisku przeczą liczne prace nad nieformalnymi instytucjami, realizowane w ramach Nowej Ekonomii Instytucjonalnej. W tym zakresie szczególnie należy zaakcentować liczne pozytywne przykłady dóbr wspólnych, zebrane i omawiane przez Elinor Ostrom, której dorobek naukowy został uhonorowany nagrodą Banku Szwecji (ekonomicznym Noblem).

W Polsce idea dobra wspólnego jest również marginalizowana. Za przykład może posłużyć ocena spółdzielczości jako formy dostarczania produktów i usług w gorszej, mniej efektywnej formie. W krańcowych przypadkach jest ona nawet traktowana jako ułomne rozwiązanie istniejących problemów. Takie stanowisko może wynikać tak z zaszłości historycznych (np. niechęci do Państwowych Gospodarstw Rolnych), jak i nadmiernego przywiazania do neoliberalizmu. $Z$ tego powodu konstytucyjne zapisy dotyczące dobra wspólnego mają niewielkie znaczenie.

Celem niniejszego opracowania jest podjęcie rozważań na temat ekonomicznych aspektów dobra wspólnego dzięki przedstawieniu charakterystycznych cech tego dobra, a także ocena relacji między dobrem wspólnym a rozwojem zrównoważonym. Ocena 
tych relacji służy zbadaniu możliwości wykorzystania dobra wspólnego we wdrażaniu koncepcji rozwoju zrównoważonego. Wymaga to zarówno zdefiniowania idei dobra wspólnego, określenia ekonomicznych aspektów jego funkcjonowania, jak i wskazania punktów wspólnych z koncepcją zrównoważonego rozwoju.

Tekst powstał na podstawie krytycznej analizy dostępnej literatury krajowej i zagranicznej. Do wnioskowania wykorzystano metodę indukcji.

\section{Dobro wspólne - charakterystyka zjawiska}

Pojęcie dobra wspólnego wywodzi się ze starożytności, jednakże nawet w czasach współczesnych jest ono rozmaicie definiowane. Różnice szczególnie są widoczne w podejściu interdyscyplinarnym, tj. wymagającym opisu na podstawie kilku nauk, zwłaszcza wobec różnic pomiędzy naukami ekonomicznymi a humanistycznymi lub prawnymi. Za główną przyczynę należy uznać rozróżnienie między dobrami publicznymi a wspólnymi, które występuje w ekonomii ${ }^{1}$. W innych naukach i w języku potocznym pojęcia te sa traktowane zamiennie, co powoduje trudności ze zrozumieniem ekonomicznej specyfiki dobra wspólnego.

Uogólniając, można wyróżnić dwa podejścia do wyjaśnienia znaczenia dobra wspólnego, a mianowicie: przedmiotowe i procesowe. W ekonomii dominuje podejście przedmiotowe. Jest ono obecne już od czasów Arystotelesa, który uważał, że dobrem wspólnym jest: dobro wlaściwe dla i osiagane tylko praez spoteczność, ale dzielone indywidualnie [Dupré, 1993, s. 687]. Kryteria konkurencyjności i wyłączenia z konsumpcji są podstawowymi sposobami rozdzielenia dóbr publicznych i wspólnych (tabela 1.). W ten podręcznikowy sposób dobra wspólne można zdefiniować jako te, w przypadku których nie można wyłączyć jednostkę z konsumpcji, przy jednoczesnej konkurencyjności w konsumpcji takiego dobra. Teoretyczny brak możliwości wyłączenia z konsumpcji powoduje, że dobra wspólne częściej są porównywane z dobrami publicznymi niż z prywatnymi, z którymi łączy je kryterium konkurencyjności w konsumpcji. Jest to o tyle znamienne, że zazwyczaj konkurencyjność w konsumpcji nie jest kwestionowana, natomiast w literaturze są podkreślane sytuacje związane $z$ wyłączeniem określonych podmiotów z konsumpcji. W praktyce są odnotowywane liczne przypadki dóbr powszechnie uznawanych za wspólne, które wykraczaja poza jedno z przyjętych kryteriów [Bollier, 2014]. Na ten problem również zwrócił uwagę L. Balcerowicz, który pisząc przedmowę do polskiego tłumaczenia książki² E. Ostrom [2013], próbował zdefiniować dobro wspólne. Posługując się wymienionymi wyżej kryteriami podziału dóbr (konkurencyjnością w konsumpcji i możliwością wyłączenia z konsumpcji) stwierdził on, że zasoby wspólne mieszczą się pomiędzy dobrami łatwo wykluczalnymi i niewykluczalnymi

1 Wspomniane rozróżnienie ma zastosowanie w dyskusji o czystych dobrach publicznych. W niektórych przypadkach, np. w ramach polityki gospodarczej, stosuje się szerokie podejście do dóbr publicznych, co sprawia, że do tej kategorii także są włączane dobra określane jako wspólne lub klubowe.

2 Warto zauważyć to, że E. Ostrom w swojej książce (uznawanej za kluczowa w odniesieniu do analizy dóbr wspólnych) nie definiuje tego pojęcia, skupiając swoją uwagę na analizie wybranych przypadków. W ten sposób wskazuje ona na wiodąca rolę nieformalnych instytucji w kreowaniu dobra wspólnego. 
$\mathrm{z}$ konsumpcji oraz $\mathrm{w}$ zależności od przypadku mogą mieć rywalizacyjny lub nierywalizacyjny charakter. Na przykład wykorzystanie zasobów naturalnych (nawet odnawialnych) może sprawiać trudności w ich konsumpcji przez inny podmiot (elektrownie wiatrowe muszą stać w odpowiedniej odległości, aby sobie wzajemnie nie przeszkadzać - nie zaburzać prądów powietrznych). Z kolei, programy komputerowe jako dobra łatwo kopiowalne, zwłaszcza w przypadku dystrybucji poprzez sieć internetowa, nie powodują konkurencyjności w konsumpcji. Praktyka powoduje więc, że te najczęściej stosowane, wręcz podręcznikowe, kryteria wyodrębniania dóbr wspólnych mają znikome zastosowanie w nauce i praktyce.

TABELA 1. Podział dóbr według kryterium konkurencyjności i wyłączenia z konsumpcji

\begin{tabular}{|c|c|c|c|}
\hline \multirow{2}{*}{ Wyszczególnienie } & \multicolumn{2}{c|}{$\begin{array}{c}\text { Możliwość wyłączenia } \\
\text { z konsumpcji }\end{array}$} \\
\cline { 3 - 4 } & TAK & NIE \\
\hline \multirow{2}{*}{$\begin{array}{c}\text { Konkurencyjność } \\
\text { w konsumpcji }\end{array}$} & TAK & dobra prywatne & $\begin{array}{c}\text { wspólne zasoby (dobra } \\
\text { wspólne) }\end{array}$ \\
\cline { 2 - 4 } & NIE & dobra klubowe & dobra publiczne \\
\hline
\end{tabular}

Źródło: opracowanie własne na podstawie: [Mankiw, Taylor, 2009].

Powyższe trudności związane z jednoznacznym zdefiniowaniem dobra wspólnego w ramach przedmiotowego podejścia przyczyniają się do tego, że coraz częściej podkreśla się procesowe aspekty, a w szczególności specyficzne relacje towarzyszące korzystaniu $z$ tego dobra. Wynika to $z$ dodatkowych cech, jakie sa przypisywane temu dobru, a pomijane w ekonomii głównego nurtu ${ }^{3}$ i bardziej zauważane w ekonomii behawioralnej. Głównie dotyczy to konieczności analizy dobra wspólnego w szerszym kontekście relacji kulturowych ${ }^{4}$, które panuja pomiędzy jego użytkownikami. Takie podejście pozwala na uchwycenie znaczenia relacji i sposobu gospodarowania dobrem wspólnym, jako czynnikami uzasadniającymi jego wyodrębnienie w naukach ekonomicznych. W ten sposób P. Barnes [2006] akcentuje, że użytkowanie dóbr wspólnych jest ograniczane tylko do członków danej społeczności, co częściowo wyjaśnia możliwość wykluczenia określonych jednostek z konsumpcji (nie należących do danej społeczności). Jak wcześniej wspomniano, istnieja liczne przypadki dóbr wspólnych, których konsumpcja jest ograniczona tylko do określonej grupy interesariuszy, co jest sprzeczne z defi-

\footnotetext{
${ }^{3}$ Główny nurt ekonomii to pojęcie, które weszło do powszechnego użytku pod koniec XX wieku [Colander, 2000]. Przyjmuje się, że jego podstawą jest ekonomia neoklasyczna, uzupełniona o zagadnienia szkoły keynesowskiej [Stankiewicz, 1998]. W szczególności należy wymienić paradygmat homo oeconomicus i wiodącą rolę rynku. Często główny nurt jest charakteryzowany za sprawą zestawu założeń, tj.: gospodarkę da się opisać za pomoca praw ekonomicznych, składa się ona z niezależnych podmiotów, jest stabilna, racjonalna i efektywna, nie faworyzuje żadnej płci, ryzykiem gospodarczym można zarządzać dzięki statystyce, wzrost gospodarczy może trwać w nieskończoność, jest zawsze dobry i da nam szczęście [Orrell, 2010].

${ }^{4} \mathrm{Na}$ temat roli kultury w gospodarce szerzej pisali m.in.: [Hausner, Karwińska, Purchla, 2013; Kleer, 2005, 2015; Thorsby, 2010].
} 
nicjami przedmiotowymi, omówionymi powyżej. Podobny sposób postrzegania dobra wspólnego jest widoczny w pracach E. Ostrom [1990]. Autorka ta nie zdefiniowała jednoznacznie opisywanego pojęcia, ale z opublikowanych prac można wywnioskować, że podstawą jej rozważań był zasób (produkt lub usługa), który trzeba analizować w kontekście otoczenia - relacji społecznych, tradycji i kultury [Ostrom, 1990; van Laerhoven, Ostrom, 2007].

Procesowe podejście jeszcze bardziej zostało uwypuklone w pracach D. Bolliera [2012; 2014], który podkreślił znaczenie długookresowych, lecz jednocześnie dynamicznych więzi społecznych, w celu zarządzania różnego rodzaju zasobami (m.in.: cyfrowymi, urbanistycznymi, naturalnymi, kulturowymi, naukowymi) lub usługami (np.: dostęp do fal morskich dla surferów, przyrost trawy na pastwisku, nawadnianie itp.). W jego rozumieniu istnieje konieczność połączenia podejścia podmiotowego i procesowego. W efekcie za dobro wspólne należy uznać sumę wspólnego zasobu oraz zestawu norm i reguł stosowanych do zarządzania nim [Bollier, 2014]. Takie podejście oznacza, że o dobru wspólnym można mówić wyłącznie w przypadku zaistnienia współużytkowania - procesu dzielenia użyteczności zasobów pomiędzy wiele jednostek. To powoduje, że kwestia prawa własności ma drugorzędne znaczenie, natomiast dobra wspólne mogą być własnością: prywatna, komunalną, państwowa, a nawet mieć charakter otwarty - open access [Fenney, Berkes, McCayi Acheson, 1990]. W rezultacie prawo własności można przyjąć za kryterium rozróżnienia między dobrem wspólnym a dobrem publicznym, zakładając, że to ostatnie jest generowane jedynie przez podmioty publiczne [Bollier, 2014] ${ }^{5}$. Takie stanowisko sprawia, że istotna staje się forma zarządzania dobrem.

Wspomniane podejście i prace D. Bolliera [2014] skłaniają do konkluzji, że dobro wspólne to każdy odnawialny zasób zarządzany kolektywnie przez grupę ludzi, w sposób uwzględniający równy dostęp i użytkowanie tego dobra (sprawiedliwe dla członków wspólnoty i wykluczające jego wykorzystywanie przez osoby nieuprawnione) oraz zrównoważone utrzymanie (zapewnienie trwałości dobra i odpowiedniej jego jakości).

\section{Dobro wspólne w teorii ekonomii}

Definiowanie dobra wspólnego przez pryzmat zachodzących procesów ma również uzasadnienie w jego ekonomicznej interpretacji. Za pierwsze prace poświęcone temu tematowi uważa się teksty napisane przez W. F. Lloyda [1833] i H.S. Gordona [1954], jednakże nie stały się one przedmiotem powszechnego zainteresowania. Dopiero podobne rozważania, opisane przez G. Hardina [1968] w słynnym artykule pt.: Tragedia dobra wspólnego, spopularyzowały negatywne nastawienie do dobra wspólnego w ramach ekonomii głównego nurtu. Hardin na przykładzie wspólnego pastwiska udowadniał,

5 Takie podejście jest także dużym uproszczeniem, ponieważ wiele dóbr publicznych może być świadczonych przez podmioty prywatne. Bardziej szczegółowe rozważania na temat różnic między dobrem publicznym a wspólnym wymagałyby oddzielnej analizy, która nie była przedmiotem niniejszej pracy. Z tego powodu ten wątek jest jedynie zasygnalizowany w celu przybliżenia znaczenia pojęcia dobra wspólnego. 
że przy założeniu racjonalnych zachowań uczestników, poszczególni rolnicy doprowadziliby do nadmiernego wykorzystania wspólnie użytkowanego zasobu i tym samym jego wyjałowienia, a nawet (w domyśle) pustynnienia. W odpowiednio długim okresie doszłoby więc do utraty części lub całości zasobów i tym samym korzyści. Z ekonomicznego punktu widzenia taka forma korzystania $z$ dobra jest nieefektywna. Autor przekonywał, że dobro wspólne jest zagrożeniem dla trwałości rozwoju i powinno być zastępowane przez własność prywatną użytkowaną tylko przez jednego właściciela.

Takie podejście zyskało aprobatę wśród neoklasycznych ekonomistów i doprowadziło do marginalizacji znaczenia dobra wspólnego w gospodarce. Na podstawie artykułu G. Hardina stworzono szereg teorii ekonomicznych, które negowały słuszność gospodarowania na zasadzie dobra wspólnego. Do najważniejszych z nich zalicza się teorię określaną jako dylemat więźnia, czyli sytuację, w której nieuczciwe zachowania moga prowadzić do osiagnięcia większych korzyści niż kooperacja.

Przekonanie o wyższej efektywności dóbr prywatnych nad wspólnymi dominuje do dziś, pomimo szeregu publikacji wskazujących liczne korzyści wynikające z zastosowania dóbr wspólnych. Do najważniejszych z nich należą prace następujących autorów: J.H. Dales [1968], C.W. Clark [1980], P.S. Dasgupta i G.M. Heal [1980], K. Rexroth [1974], Ch. Hill [1972], P.J. Proudhon [1994], Ch. Fourier [1996], D. Lummis [1997] oraz J. H. Mitchel [1998]. Przede wszystkim warto zwrócić uwagę na przytaczaną już pracę E. Ostrom, która jednoznacznie udowodniła, że G. Hardin mylił się. Jego wspólne pastwisko nie jest w żaden sposób zarządzane, co powoduje, że nie ma charakteru dobra wspólnego. Badane przez tę autorkę liczne przykłady zarządzania dobrami wspólnymi pokazuja, że wykształcenie się, często nieformalnych, instytucji nadzoru nad dobrem wspólnym prowadzi do skutecznego zabezpieczenia przed nadmiernym zużyciem. Bez takich regulacji dobro wspólne przestaje być wspólnym, staje się jedynie zasobem dostępnym dla wszystkich. Wspomniane instytucje są szczególnie efektywne, gdy mają charakter oddolny, tj. są efektem wspólnego stanowiska interesariuszy, a nie narzuconym odgórnie narzędziem kontroli. Co więcej, E. Ostrom stwierdziła, że to właśnie sposób społecznego nadzoru nad dobrem wspólnym jest elementem odróżniającym je od innych dóbr. W ten sposób można wysnuć wniosek, że definicje opisujące dobro wspólne poprzez procesy mają większą wartość niż charakterystyki oparte na kryterium przedmiotowym. Dodatkowo można pokusić się o konstatację, że nieformalne instytucje są istotnym kryterium rozróżnienia między dobrami wspólnymi a publicznymi, ponieważ to interesariusze są jednocześnie organem kontrolnym. W tym drugim przypadku, niezależnie od formy własności, zawsze istnieje określona forma odgórnej kontroli sprawowanej przez suwerena.

Negacja pozytywnego znaczenia dobra wspólnego w gospodarce wynika również z błędnego pojmowania uwarunkowań, w jakich znajduje się człowiek. Rynek może istnieć wyłącznie w przestrzeni publicznej. Jest ona niezbędna do prawidłowego kształtowania i nadzorowania rynku. Instytucje publiczne, będące swego rodzaju dobrami publicznymi, są nieodzownym elementem ładu publicznego. Podobnie jest z dobrami wspólnymi. Osiagnięcie celów istotnych dla całej społeczności może być bardziej efektywne dzięki wspólnemu zarządzaniu dobrem niż indywidualnemu sprawowaniu nadzoru za pomocą własności prywatnej. 
Jednak takie podejście wiąże się z akceptacją tego, iż w niektórych przypadkach paradygmat ekonomii głównego nurtu, tj. wyjaśnienie zachowań ludzkich za sprawą modelu homo oeconomicus oraz dążenie do maksymalizacji zysku w kontekście skali mikroekonomicznej i krótkiego okresu, nie powoduje osiagnięcia optymalnych korzyści [Prandecki, Gajosi Buks, 2015]. Jest to następstwem pominięcia części korzyści niemożliwych do wyceny w wartościach pieniężnych (efektów zewnętrznych) w rachunku ekonomicznym. W tym zakresie konieczne jest uwypuklenie trwałości i bezpieczeństwa. Liczne przykłady dóbr wspólnych prowadzą do wniosku, że w przeciwieństwie do przytaczanych twierdzeń G. Hardina, dobro wspólne charakteryzuje się bardziej długookresową dbałością o dany zasób niż ma to miejsce we współczesnej gospodarce kapitalistycznej, w której destrukcja istniejącego zasobu, np. w postaci fabryki na rzecz osiagnięcia krótkookresowych korzyści, jest nie tylko dopuszczalna, ale wręcz może być uważana za sukces. Zazwyczaj zasób uznany za dobro wspólne funkcjonuje nieprzerwanie, o czym moga świadczyć kilkusetletnie przykłady wykorzystywania alpejskich łąk czy też zasobów hiszpańskich rzek na zasadach dobra wspólnego. W tych przypadkach maksymalizacja użyteczności jest liczona długookresowo, tj. zasób może być wykorzystywany tylko w taki sposób, aby dostęp do niego był zapewniony przez cały cykl rozliczeniowy, przy jednoczesnym zapewnieniu zdolności odtwórczych. Tym samym w okresie suszy zasób wody do nawadniania jest rozdzielany w sposób proporcjonalny do potrzeb wszystkich użytkowników. W odniesieniu do własności prywatnej i braku odpowiednich regulacji (rozwiązywanie problemów wyłącznie przez rynek) można spodziewać się maksymalizacji konsumpcji wody przez pierwszego użytkownika, kosztem kolejnych rolników. Analogicznie jest regulowany podział obowiązków związanych z utrzymywaniem zasobu w należytej jakości. W przypadku wody oznacza to np. odpowiednią dbałość o stan kanałów.

Negatywne nastawienie do dobra wspólnego w ramach ekonomii neoklasycznej sprawia, że do jego stosowania należy poszukiwać uzasadnień w innych nurtach tej naukí. W tym zakresie wyróżnia się trzy obszary:

- ekonomię behawioralną, w której podjęto krytykę koncepcji homo oeconomicus, co jest podstawą objaśniania niedoskonałości wyceny wartości dobra opartej jedynie na pieniądzu (człowiek może także kierować się innymi pobudkami, które dają równie wielką satysfakcję);

- Nową Ekonomię Instytucjonalną (NEI), która tłumaczy istotną rolę instytucji, zwłaszcza nieformalnych, w rozwoju gospodarczym;

- ekonomię zrównoważonego rozwoju, która podkreśla znaczenie i prymat trwałości rozwoju nad maksymalizacją krótkookresowych korzyści.

${ }^{6}$ Niniejsze stwierdzenie jest pewnego rodzaju uproszczeniem. W ramach ekonomii głównego nurtu istnieją teorie dotyczące m.in. dynamiki systemów, które wskazują na konieczność wprowadzania regulatorów rynku umożliwiających pohamowanie nieograniczonego pędu bomo oeconomicus do maksymalizacji zysku i w ten sposób trwałe korzystanie ze wspólnego dobra [Dacko, Bielecka, 2015; Senge, 2012]. Jednakże należałoby rozważyć, czy te modele są jeszcze zgodne z teorią ekonomii neoklasycznej lub keynesowskiej, czy też bardziej zaliczają się do Nowej Ekonomii Instytucjonalnej. 
Spośród powyższych trzech nurtów zdecydowanie największe zastosowanie w ekonomicznym wyjaśnieniu dobra wspólnego ma NEI, choć w wielu przypadkach nie jest to wystarczające.

Konsekwencją takiego wycinkowego uzasadniania sensu istnienia dóbr wspólnych jest próba stworzenia oddzielnego nurtu - ekonomii dobra wspólnego [Felber, 2014], lecz na obecnym etapie rozwoju nurt ten bardziej składa się z postulatów niż naukowych podstaw. Powszechnie zauważa się, że stworzenie nowego nurtu - ekonomii dobra wspólnego - wymaga zmiany paradygmatu ekonomii [Bollier, 2012; Economics and the Common(s)..., 2013; Houtart, 2012; Jamka, 2014]. Nie jest on jednoznacznie zdefiniowany, mimo to można założyć, że w głównej mierze wiązałoby się to z włączeniem kwestii etycznych i moralnych do oceny wartości dobra oraz ze zwiększeniem znaczenia rozwoju (w tym niematerialnego), kosztem wzrostu gospodarczego (liczonego za pomocą PKB). Jednak zmiana paradygmatu łączy się z konsensusem społecznym, trudno więc spodziewać się, aby nastapiło to szybko. Taka przemiana wymaga nie tylko przełamania barier kulturowych wobec nowego podejścia do wartości i gospodarki, ale również odpowiedniego aktora (podmiotu zbiorowego) zdolnego do przeprowadzenia zmian. Jamka [2014] stwierdził, że taką grupa może być pokolenie $\mathrm{Y}$, jednakże jego wiodąca rola w społeczeństwie będzie widoczna dopiero w perspektywie około 20 lat.

\section{Dobro wspólne w kontekście zrównoważonego rozwoju}

Zgodnie z najbardziej rozpowszechnioną definicja, rozwój zrównoważony to: rozwój zgodny z potrzebami obecnych pokolen, nie umniejszajacy mo:̀liwości prayszłych pokolen do zaspokajania swoich potrzę [Our common future, 1987]. Istota tej koncepcji jest więc kierowanie trendami rozwojowymi w taki sposób, aby zapewnić trwałość cywilizacji ludzkiej w możliwie jak najlepszych warunkach. Wymogiem do osiagnięcia tego celu jest zapewnienie równorzędnych relacji pomiędzy sferą gospodarczą, społeczną i środowiskowa. Takie uogólnienie i wielość interpretacji powoduje, że zrównoważony rozwój jest koncepcją, którą można dopasować do wielu teorii ekonomicznych. W praktyce jego elementy mogą być zgodne zarówno z ekonomia głównego nurtu, co m.in. jest obserwowane w polityce Unii Europejskiej, jak i bardziej restrykcyjnymi nurtami, np. z ekonomia ekologiczna. W tym ostatnim przypadku zakłada się, że gospodarki świata powinny rozwijać się jedynie dzięki wykorzystywaniu zasobów odnawialnych i to w skali umożliwiającej ich odtwarzanie [Daly, Farley, 2010]. Takie nastawienie często traktuje się jako restrykcyjne podejście do zasady trwałości ${ }^{7}$. Najnowszy

\footnotetext{
7 Zasada trwałości określa relacje pomiędzy różnymi składowymi kapitału. W teorii występuje ona w czterech postaciach: słabej - oznaczającej zachowanie jedynie wielkości całego kapitału, bez uwzględnienia jego struktury (kapitał przyrodniczy wytworzony przez człowieka i społeczny); wrażliwej - wymagającej, aby poza zachowaniem całkowitej wielkości kapitału, pozostała nienaruszona pewna część w ramach relacji pomiędzy składowymi; silnej - wymagającej, by poszczególne rodzaje kapitału zostały zachowane każdy z osobna, ponieważ uznaje się, że np. kapitał przyrodniczy i wytworzony przez człowieka nie są względem siebie substytucyjne; restrykcyjnej - oznaczającej całkowity zakaz uszczuplania jakiegokolwiek
} 
nurt powiązany z ekonomią ekologiczną jest określany jako gospodarka umiaru [Coyle, 2012; Dietz, O’Neil, 2013].

Uogólniając, należy podkreślić, że koncepcja zrównoważonego rozwoju jest nastawiona na takie świadome kształtowanie przyszłości, aby osiagnąć możliwie najwyższa jakość życia. Przy czym ta jakość życia jest szeroko interpretowana, co oznacza uwzględnienie w jej ocenie nie tylko wskaźników gospodarczych, ale również trudniej mierzalnych kryteriów społecznych i środowiskowych.

Analizę relacji pomiędzy dobrem wspólnym a zrównoważonym rozwojem warto prowadzić na dwóch płaszczyznach: jednostkowej - określającej przydatność konkretnych rozwiązań do osiagnięcia celów zrównoważonego rozwoju oraz na płaszczyźnie teoretycznej, tj. porównania koncepcji ekonomii dobra wspólnego i zrównoważonego rozwoju.

Punktem wyjścia jest ocena jednostkowa, czyli identyfikacja dóbr (i ich grup) do oceny zasadności zastosowania w ramach zrównoważonego rozwoju. Jak wcześniej wskazano, gospodarowanie na zasadach dobra wspólnego najczęściej jest wykorzystywane w odniesieniu do dóbr rywalizacyjnych, w przypadku których zazwyczaj nie ma możliwości wyłączenia części interesariuszy z konsumpcji. Dobra wspólne mogą występować na różnych poziomach, a mianowicie: lokalnym, regionalnym (państwowym) i globalnym. Takie zarządzanie dobrem jest skuteczne m.in. w stosunku do zasobów odnawialnych. $Z$ tego powodu dobrem wspólnym mogą być np. lokalne zasoby wody, lasy, m.in. Puszcza Białowieska (zasób istotny zarówno lokalnie, jak i regionalnie) czy też programy komputerowe rozpowszechniane na całym świecie, na zasadach creative commons. Czynnikiem, który je wyróżnia, jest zapewnienie trwałości korzystania z zasobu oraz zarządzanie nim dzięki regułom ustalonym i nadzorowanym przez całą społeczność. Oznacza to, że dobra wspólne nie muszą ograniczać się jedynie do kwestii czysto środowiskowych (z czym są najczęściej utożsamiane - np. hardinowskie wspólne pastwisko), ale mogą również mieć zastosowanie w sferze społecznej. W ten sposób można traktować różnego rodzaju inicjatywy związane z wymianą wiedzy bądź zasobów. W tym ostatnim przypadku za przykład może posłużyć bezpłatna wymiana ziarna w wybranych regionach wiejskich Indii. Mieszkający tam rolnicy (głównie kobiety) celowo mieszają różne gatunki i odmiany zbóż, by otrzymać plon możliwie w największym stopniu odporny na kryzysy (upał, suszę, powodzie, mrozy itp., zjawiska klimatyczne). Tym samym dochodzi także do wzbogacenia puli genetycznej zbóż i wzmocnienia ich odporności na różne choroby. Proces wymiany jest istotny nie tylko ze względu na zachowanie różnorodności biologicznej, lecz przede wszystkim służy zapewnieniu stabilności zaopatrzenia lokalnych społeczności w żywność. Mieszanie zbóż powoduje pozornie mniejsza produktywność i trudności ze sprzedażą zanieczyszczonego zboża, lecz jednocześnie zapewnia uzyskanie plonów praktycznie niezależnie od warunków pogodowych (np. zmian klimatycznych), a więc długookresowo zwiększa bezpieczeństwo żywnościowe lokalnych społeczności. Wobec czego jest zachowana nie tylko zdolność przetrwania wioski, ale również trwałość gospodarowa-

z zasobów nieodnawialnych i użycie odnawialnych jedynie do granicy możliwości jego odtworzenia [Borys, 2005]. 
nia na danym terenie. Warto zauważyć, że istnieje wiele podobnych przykładów trudnych do wyceny korzyści, które wynikają z dóbr wspólnych.

Uogólniając, zapewnienie bezpieczeństwa i trwałości dostępu do zasobu jest charakterystyczne zarówno dla dobra wspólnego, jak i zrównoważonego rozwoju. Oznacza to, że dobro wspólne może być wykorzystywane do realizacji celów zrównoważonego rozwoju. Ponadto, liczne możliwości zastosowania dóbr wspólnych przyczyniaja się nie tylko do zwiększenia trwałości ładu środowiskowego, a zarazem społecznego i gospodarczego. Wspólne zarządzanie takim dobrem umożliwia zacieśnienie więzi społecznych w ramach grupy interesariuszy, co dodatkowo pozwala na zwiększenie współpracy w innych obszarach.

Należy podkreślić, że gospodarowanie na zasadach dobra wspólnego jest szczególnie wskazane w przypadkach, gdy mamy do czynienia z rywalizacyjnym wykorzystaniem środowiska. W ten sposób za przyczyną konsensusu opartego na instytucjach kontrolnych tworzonych oddolnie, działających dzięki podstawom naukowym dotyczącym możliwości bezpiecznego korzystania z dobra, można gospodarować: lasami, pięknem krajobrazu (może to prowadzić do utraty części krótkookresowych korzyści, jakie niektórzy interesariusze mogliby uzyskać) oraz zasobami odnawialnymi, np. woda w rolnictwie (warto przypomnieć, że dawniej we wsiach istniały stawy, które funkcjonowały na zasadach dobra wspólnego, służące do zapewnienia dostępu do wody dla całej społeczności). Dobro wspólne w koncepcji zrównoważonego rozwoju może być równocześnie wykorzystywane do realizacji celów społecznych i gospodarczych. Za przykład moga posłużyć wszelkiego rodzaju spółdzielnie. Mogą one wzmacniać pozycję rynkową małych producentów, czyli przyczyniać się do bardziej sprawiedliwego rozdziału zysków (np. w wyniku eliminacji pośredników - producent żywności dzięki spółdzielni może być jednocześnie jej przetwórca). Ten sam efekt może być osiagnięty przez wypłacanie członkom spółdzielni odpowiednich dywidend. W ekonomii klasycznej praca była traktowana na równi z kapitałem i ziemia. Współcześnie kapitał jest uważany za „lepszy” z czynników pracy. Z tego powodu inwestującym kapitał należą się dywidendy od zysków, a pracownikom inwestującym czas i wiedzę już nie. Rozdzielanie zysków na zasadzie dobra wspólnego przez wyliczenie znaczenia: wkładu pracy, wiedzy i kapitału w przedsiębiorstwo (spółdzielnię) powinno być odpowiednio wynagradzane.

Na płaszczyźnie teoretycznej można wyróżnić trzy główne zagadnienia, które określaja zbieżność relacji między ekonomią dobra wspólnego a zrównoważonym rozwojem. Zalicza się do nich: podejście do konsumpcji, paradygmat maksymalizacji zysku oraz interpretację pojęcia zasobu.

Największe znaczenie ma kwestia konsumpcji, której ograniczenie coraz częściej jest poruszane $\mathrm{w}$ teoriach opartych na zrównoważonym rozwoju (np. ekonomii ekologicznej czy ekonomii umiaru). W literaturze wręcz wskazuje się na konieczność posługiwania się pojęciem zrównoważonej konsumpcji, która uwzględniałaby społeczne i środowiskowe aspekty wykorzystywania różnych dóbr i usług [Kiełczewski, 2004]. W ekonomii dobra wspólnego konsumpcja ma drugorzędne znaczenie. W literaturze problem ten jest traktowany marginalnie, jednakże ze względu na postulat trwałości można przyjąć, że konsumpcja musi być ograniczana do poziomu zdolności od- 
tworzenia zasobu. Tak jest m.in. w przypadku zarządzania wspólnymi pastwiskami. Generalizując, można założyć, iż poglądy w zakresie konsumpcji, w tych dwóch koncepcjach są zbieżne.

Wspólne cechy można również zauważyć w podejściu do maksymalizacji zysku. Prymat długookresowych celów nad krótkookresowym zyskiem powoduje, że oprócz wartości wycenianych w pieniądzu, obie koncepcje kładą nacisk na wartości nieuwzględniane w rachunku ekonomicznym. Nie jest to celem tych koncepcji, ale efektem ubocznym. W ramach zrównoważonego rozwoju akcentuje się rozwój, a w ekonomii dobra wspólnego bezpieczeństwo, jednakże można przyjąć, że obie te koncepcje dążą do osiągnięcia optimum społecznego (różnie opisywanego), kosztem optimum ekonomicznego (maksymalizacji zysku). Wydaje się, że optimum społeczne, oparte na dobru wspólnym, jest bardziej zawężone.

Ostatnim z obszarów wymagających oceny jest interpretacja pojęcia zasobu. Badacze dobra wspólnego ukazali pozornie szerszy zakres znaczenia badanego pojęcia w ramach ich koncepcji [Jamka, 2014]. Wyróżnili oni kapitał (zasób): materialny (dotyczący obiektów fizycznych), ludzki (określający cechy i właściwości poszczególnych osób) oraz społeczny (odnoszący się do relacji pomiędzy ludźmi). Niejednokrotnie podkreśla się, że elementy tych kapitałów mogą mieć charakter niematerialny. W praktyce podobne stanowisko jest widoczne w ramach zrównoważonego rozwoju, gdzie poza zasobami materialnymi i procesami środowiskowymi, istotną rolę odgrywają także relacje społeczne (zjawiska niematerialne). Świadczyć o tym może m.in. postulat wyodrębnienia z kapitału społecznego i nadania większej wagi oddzielnej grupie, jaką miałby być ład kulturowy [Thorsby, 2010].

Zbieżności w powyższych obszarach, jak również zbliżone poglądy w zakresie negacji neoklasycznego podejścia do gospodarki, uznania podstawowej roli instytucji w kreowaniu nowego porządku świata czy też narastającej potrzeby planetarnego traktowania niektórych zasobów prowadzą do przekonania, że nawet w przypadku rozwoju ekonomii dobra wspólnego jako oddzielnego nurtu ekonomii istnieje zasadność stosowania dobra wspólnego do realizacji celów zrównoważonego rozwoju.

\section{Podsumowanie}

Powyższe rozważania na temat relacji między dobrem wspólnym a zrównoważonym rozwojem pozwalają na wyciągnięcie kilku ogólnych wniosków. Po pierwsze, istnieje potrzeba dalszych teoretycznych i empirycznych badań nad dobrem wspólnym w celu bardziej precyzyjnego jego zdefiniowania i opisania. Po drugie, dobro wspólne może być skutecznym narzędziem realizacji zrównoważonego rozwoju. W zależności od warunków, korzyści płynące z takiego rozwiązania moga dotyczyć wszystkich trzech podstawowych ładów, tj.: gospodarczego, społecznego i środowiskowego.

Powyższe wnioski wymagają dalszego uszczegółowienia. Przede wszystkim należy podkreślić, że dobro wspólne nie jest tylko zasobem (przedmiotem lub usługa), ale również relacją społeczną związaną z jego zarządzaniem. Z tej racji definicje uwzględniające jego procesowe aspekty mają większe uzasadnienie. 
W ekonomii głównego nurtu dobro wspólne jest uznawane za nieefektywne rozwiązanie, co prowadzi do prób wyodrębnienia nowego nurtu - ekonomii dobra wspólnego. Porównanie postulatów tego nurtu z założeniami zrównoważonego rozwoju skłania do konstatacji, że w ogólnych założeniach koncepcje te są zbieżne, a wielu badaczy usilnie próbuje znaleźć różnice pomiędzy nimi. To powoduje, że w szczegółach mogą one różnić się od siebie. Jednakże różnice te są niewielkie i nie przeszkadzają w wykorzystaniu dobra wspólnego do realizacji celów zrównoważonego rozwoju. Jest to widoczne zwłaszcza na poziomie mikroekonomicznym, tj. w przypadku oceny poszczególnych rozwiązań. Liczne przykłady publikowane w literaturze pokazuja, że za pomocą dobra wspólnego można osiagnąć długookresową trwałość (nawet obejmująca kilkaset lat) wykorzystania dobra. To pozwala na stwierdzenie, że dzięki dobru wspólnemu (w wybranych obszarach) może być osiagnięty główny cel zrównoważonego rozwoju.

Przedstawione rozważania umożliwiaja sformułowanie takiej konkluzji, iż w kontekście zrównoważonego rozwoju dobro wspólne nie musi być wykorzystywane wyłącznie do realizacji celów środowiskowych (gdzie jego efektywność jest najbardziej oczywista), lecz zarazem do osiagnięcia celów społecznych, także w ramach działalności gospodarczej. To sprawia, że ma ono uniwersalny charakter, a spektrum oddziaływania będzie zależeć jedynie od świadomości i potrzeb interesariuszy. Istotne jest, aby pamiętać, że realizacja dobra wspólnego w możliwie jak największym stopniu powinna być oparta na oddolnych, niekoniecznie formalnych instytucjach, ponieważ one przyczyniają się do utożsamiania się członków lokalnej społeczności z danym dobrem.

\section{Literatura}

Barnes P., 2006, Capitalism 3.0: A Guide to Reclaiming the Commons, Berrett-Koehler Publishers, San Francisco.

Bollier D., 2012, Dobro wspólne jako nowy paradygmat, P2P Foundation, http://p2pfoundation.net/DOBRO_WSP\%C3\%93LNE_JAKO_NOWY_PAR ADYGMAT (data wejścia: 13.10.2015).

Bollier D., 2014,The Commons Dobro wspólne dla każdego, Faktoria, Zielonka.

Borys T., 2005, Waskie i sžerokie interpretacje zrónnoważonego rozwoju oraz konsekwencje wyboru, [w:] Zrónnoważony rozwoój od utopii do praw č̨łowieka, W. A. Papuziński (red.), Oficyna Wydawnicza Branta, Bydgoszcz.

Clark C. W., 1980, Restricted Access to Common-Property Fishery Resources: a Game Theory Analysis, [in:] Dynamic Optimization and Mathematical Economics, P.T. Liu (red.), Plenum Press, New York.

Colander D. C., 2000, Complexity and the History of Economic Thought, Routledge, New York.

Coyle D., 2012, The Economics of Enough: How to Run the Economy as If the Future Matters, Princeton University Press, Princeton.

Dacko M., Bielecka P., 2015, Dynamika systemów jako narzedzie przeciwdziałania tragedii dóbr wspólnych, „Ekonomia i Środowisko”, nr 2(53). 
Dales J. H., 1968, Pollution, Property, and Prices: An Essay in Policy-making and Economics, University of Toronto Press, Toronto.

Daly H. E., Farley J., 2010, Ecological Economics. Principles and Applications, Island Press, Washington.

Dasgupta P. S., Heal G.M., 1980, Economic Theory and Exhaustible Resources, Cambridge University Press, Cambridge.

Dietz R., O'Neil D., 2013, Enough is enough. Building a Sustainable Economy in a World of Finite Resources, Berrett-Koehler Publishers, Inc., San Francisco.

Dupré L., 1993, The Common Good and the Open Society, The Review of Politics, (55(04)), s. 687-712, http://dx.doi.org/10.1017/S0034670500018052.

Economics and the Common(s): From Seed Form to Core Paradigm A report on an international conference on the future of the commons, 2013, Heinrich Böll Foundation, Commons Strategies Group, Charles Léopold Mayer Foundation and Remix the Commons, https://www.boell.de/sites/default/files/ecc_report_final.pdf (data wejścia: 13.10. 2015).

Felber C., 2014, Gospodarka dobra wspólnego, Wydawnictwo Biały Wiatr, Rzeszów.

Fenney D., Berkes F., McCay B., Acheson J., 1990, The Tragedy of the Commons: Twenty-two Years Later, „Human Ecology”, no. 18 (1).

Fourier C., 1996, The Theory of Four Movements, Cambridge University Press, Cambridge.

Gordon H. S., 1954,The Economic Theory of a Common-Property Research: The Fishery. „The Journal of Political Economy”, no. 62 (2).

Grubb M., 2014, Planetary Economics: Energy, climate change and the three domains of sustainable development, Routledge, New York.

Hardin G., 1968, The Tragedy of the Commons, "Science", 162.

Hausner J., Karwińska A., Purchla J., 2013, Kultura a rozwój, Narodowe Centrum Kultury, Warszawa.

Hill C., 1972, The World Turned Upside Down: Radical Ideas During the English Revolution, Maurice Temple Smith, London.

Houtart F., 2012, From 'common goods' to the 'Common Good of Humanity', [in:] A Postcapitalist Paradigm: The Common Good of Humanity, B. Daiber, F. Houtart (eds.), Rosa Luxemburg Foundation, Brussels.

Jamka B., 2014, Ekonomia dobra wspólnego - budowa nowego paradygmatu, „Myśl Ekonomiczna i Polityczna, nr 1.

Kiełczewski D., 2004, Konsumpcja a perspektywy trwałego i zrównoważonego rozwoju, Wydawnictwo Uniwersytetu w Białymstoku, Białystok.

Kleer J., 2005, Globalne dobra publiczne a państwo narodowe (No. 267), Instytut Gospodarki Światowej Szkoły Głównej Handlowej, Warszawa.

Kleer J., 2015, System kulturowy a myślenie strategicæne, „Biuletyn PTE”, nr 2 (69).

Lloyd W.F., 1833, Two Lectures on the Checks to Population, S. Collingwood, Oxford.

Lummis D., 1997, Radical Democracy, Cornell University Press, Ithaca.

Mankiw N.G., Taylor M.P., 2009, Mikroekonomia, Polskie Wydawnictwo Ekonomiczne, Warszawa. 
Mitchel J.H., 1998, Trespassing: An Inquiry into the Private Ownership of Land, Perseus Books, Reading, MA.

Orrell D., 2010, Economyths: Ten Ways Economics Gets It Wrong, Wiley, Mississauga.

Ostrom E., 1990, Governing the Commons: The Evolution of Institutions for Collective Action, Cambridge University Press, Cambridge, New York.

Ostrom E., 2013, Dysponowanie wspólnymi zasobami, Wolters Kluwer Business, Warszawa.

Our common future(document A/42/427), 1987, World Commission on Environment and Development, http://www.un-documents.net/wced-ocf.htm (data wejścia: 13.09.2010).

Prandecki K., 2014, Racjonalność planetarna jako narz̨dzie realizacji zrównoważonego rozwoju, „Ekonomia i Środowisko”, nr 2(49).

Prandecki K., Gajos E., Buks J., 2015, Z badań nad rolnictwem społecznie zrównoważonym [32]. Efekty zemnetrzne i dobra wspólne w rolnictwie - identyfikacja problemu, Instytut Ekonomiki Rolnictwa i Gospodarki Żywnościowej, Państwowy Instytut Badawczy, Warszawa.

Proudhon P. J., 1994, What is Property, Cambridge University Press, Cambridge.

Rexroth K., 1974, Communalism: From Its Origins to the Twentieth Century, Seabury Press, New York.

Senge P. M., 2012, Piata dyscyplina. Teoria i praktyka organizacji uczacych sie, Wolters Kluwer Polska, Warszawa.

Stankiewicz W., 1998, Historia myśli ekonomicznej, Polskie Wydawnictwo Ekonomiczne, Warszawa.

Thorsby D., 2010, Ekonomia i kultura, Narodowe Centrum Kultury, Warszawa.

van Laerhoven F., Ostrom E., 2007,Traditions and Trends in the Study of the Commons, „International Journal of the Commons”, 1(1).

Wall D., 2014,The Sustainable Economics of Elinor Ostrom: Commons, contestation and craft, Routledge, London, New York. 